\title{
A Systematic Review Regarding Tonometry and the Transmission of Infectious Diseases
}

\author{
Nicole Atkins ${ }^{\mathrm{a}}$, William Hodge ${ }^{\mathrm{b}, \mathrm{c}, \mathrm{e}}$, Bruce Li ${ }^{\mathrm{d}}$
}

\begin{abstract}
Tonometry has been identified as a common method for measuring the intraocular pressure in patients. The direct contact between the tonometer and the eye may contribute to the risk of cross infection, especially of viral particles, from one patient to another. A systematic review was undertaken to address the likelihood of human immunodeficiency virus (HIV), hepatitis B virus, hepatitis $\mathrm{C}$ virus, and prion diseases transmission through the use of tonometers. Additionally, a comparison of the current tonometer disinfection methods is provided to assist with identifying which technique effectively reduces the risk of disease transmission. An electronic literature search was conducted using the following databases: Web of Science, EMBASE, CINAHL, SCOPUS, Biosis Previews, Cochrane Library, PubMed, and Google Scholar. Dissertation indexes were also searched, and these included: Dissertations and Abstracts, and Dissertations and Abstracts - UK/ Ireland. Additionally, the Clinicaltrials.gov trial registry was searched to identify any other relevant literature. Two independent reviewers critically appraised the articles retrieved through the literature search. In total, 11 unique studies were deemed relevant for this systematic review. The available evidence demonstrated that the use of tonometers contributes to the transmission of these infectious diseases in vitro. The results also demonstrated variability in determining the most effective tonometer sterilization technique against these infectious diseases in vitro. There was limited evidence available regarding the transmission of HIV, hepatitis B, hepatitis C, and prion diseases through the use of tonometers. Additionally, due to the variability regarding the most effective sterilization techniques, it is difficult to identify which sterilization technique is most effective or adequately effective against these infectious diseases. Future research studies regarding infectious disease transmission through tonometry and sterilization techniques should be completed to more adequately inform
\end{abstract}

Manuscript submitted December 6, 2017, accepted January 2, 2018

aPublic Health Program, Western University, London, ON N6A 3K7, Canada bDepartment of Ophthalmology, Western University, London, ON N6A 3K7, Canada

'Department of Epidemiology, Western University, London, ON N6A 3K7, Canada

dMedical Sciences Program, Western University, London, ON N6A 3K7, Canada

${ }^{\mathrm{e} C}$ Corresponding Author: William Hodge, Department of Ophthalmology, Western University, London, ON N6A 3K7, Canada.

Email: William.Hodge@sjhc.london.on.ca

doi: https://doi.org/10.14740/jocmr3294w infectious disease control guidelines.

Keywords: Tonometry; Transmission; Infectious disease; Cross infection; Sterilization

\section{Introduction}

Globally, glaucoma is considered to be the second leading cause of blindness, and 60 million people have been diagnosed with this condition [1]. Glaucoma results in damage to the optic nerve and its most important risk factor is increased intraocular pressure. The optic nerve is responsible for transferring visual stimuli to the occipital lobe of the brain [2]. The optic nerve damage associated with glaucoma contributes to an asymptomatic decline in visual function, and these effects are often irreversible [2]. Approximately, $50 \%$ of those with glaucoma are unaware of their condition during the early stages of this disease [2]. Consequently, the early diagnosis of glaucoma is essential to preserving the visual function within individuals [3].

Assessing the specific changes in the intraocular pressure in patients over time is essential to diagnosing and treating patients with glaucoma. For the past 50 years, tonometry has been identified as a common method for measuring the intraocular pressure in patients [4]. Specifically, the Goldmann applanation tonometer (GAT) is currently the most widely used tonometer in clinical settings amongst ophthalmologists [5]. The process of tonometry involves the application of a topical anesthetic to the surface of the eye [6]. Subsequently, the head of the tonometer comes into direct contact with the eye surface, to measure the intraocular pressure [6].

The direct contact between the tonometer and the eye contributes to the risk of cross infection, especially of viral particles, from one patient to another [7]. The risk of transmission is associated with the retention of corneal epithelial cells on the tonometer tips following the measurement of intraocular pressure [8]. Previous experimental research studies have identified that hepatitis $B$ virus, hepatitis $C$ virus, human immunodeficiency virus (HIV), and variant Creutzfeldt-Jakob disease are transmissible through direct contact with the eye [9]. Consequently, there are growing concerns regarding the potential risk of infection transmission through the use of tonometry [6]. Prevention of all infectious diseases is desirable; however, it is especially crucial to prevent the transmission of HIV and hepatitis C virus [10]. Preventing the spread of these 
diseases is essential as immunizations are currently not available to assist in providing protection against transmission [10].

The disinfection methods for tonometers currently vary in ophthalmic and optometry clinics worldwide [11]. Hygienic practices, such as hand washing, have been identified as the first step to reducing the spread of infectious diseases [10]. The Canadian Ophthalmological Society requires that tonometer tips are disinfected between patients; however, instructions regarding a specific sterilization technique have not been provided [11]. There is variation amongst the sterilization techniques chosen to disinfect tonometer tips, and controversy continues to exist regarding the most effective method of sterilization [12]. A national survey has identified that alcohol swabs are the primary disinfectant technique amongst $71 \%$ of Canadian ophthalmologists, who participated in the survey [12]. The current published literature also suggests several other disinfection methods, including: placing the tonometer tip in running water, wiping the tonometer tip with at least two surfaces of a clean cotton ball (soaked with water or saline), cleaning with a dry tissue, and the use of alcohol or detergents for disinfection [11]. Tonometer prisms may also be disinfected by soaking the tips in a peroxide solution [13]. Nevertheless, soaking the tonometer tips is usually an unfavourable technique as the process is time consuming, costly, contributes to tip destruction, and may lead to iatrogenic corneal toxicity [12]. Additionally, the use of disposable tonometer prisms has been proposed to reduce the risk of infectious disease transmission [14]. However, the use of disposable tonometer tips is costly in clinical settings, and concerns have been expressed regarding the accuracy of these disposable tips [13]. Despite the numerous sterilization techniques available to reduce the transmission of infectious diseases, previous research studies have identified that there is incomplete sterilization of tonometer prisms in ophthalmic clinics [14]. Incomplete sterilization of tonometer prisms is partly attributable to the time consuming nature of the disinfection process, which is prone to error [6]. Thus, failure to effectively disinfect tonometer tips could result in an increased likelihood of infectious disease transmission.

This article contains a systematic review, which addresses the likelihood of HIV, hepatitis B virus, hepatitis C virus, and prion diseases transmission through the use of tonometers. Additionally, this systematic review will also compare the current tonometer disinfection methods, and review which sterilization techniques effectively reduce the risk of disease transmission. Currently, more than 122 million patients undergo tonometry annually worldwide [12]. Consequently, it is essential for clinicians, hospital administrators, and politicians to be informed on the most effective disinfection methods against these infectious diseases. The identification of evidence-based sterilization techniques within this systematic review could assist with informing the infection control guidelines for optometry and ophthalmic clinics.

\section{Methods}

\section{Search strategy}

The search strategy implemented for this systematic review was designed to be comprehensive and attain the maximum possible collection of relevant literature. An electronic search strategy was established by an information specialist librarian, in consultation with a Master of Public Health student, and a clinical medical expert in tonometer sterilization. The searches completed for this project were not restricted based on the date of publication or study type. Published and unpublished studies were considered for this review regardless of design type. However, searches were restricted to studies published in the English language. Studies that contained information regarding tonometry and hepatitis B, hepatitis $\mathrm{C}, \mathrm{HIV}$, and prion disease transmission were retrieved. Additionally, studies that included tonometry sterilization techniques against these infectious diseases were included for this review. Specific search terms relating to tonometry, sterilization, hepatitis $\mathrm{B}$, hepatitis $\mathrm{C}, \mathrm{HIV}$, and prion disease were used in the search strategy. Studies that looked at common red eye pathogens such as adenovirus were not studied as this topic has been reviewed elsewhere [12].

The electronic databases searched for this project were as follows: Web of Science, EMBASE, CINAHL, SCOPUS, Biosis Previews, Cochrane Library, PubMed, and Google Scholar. Dissertation indexes were also searched, and these included: Dissertations and Abstracts, and Dissertations and Abstracts UK/Ireland. Additionally, the Clinicaltrials.gov trial registry was searched to identify any other relevant literature. The vocabulary and key words used in the search included terms relating to tonometry, sterilization, hepatitis B, hepatitis C, HIV, and prion disease. The search strategy was conducted to a final date of May 24, 2017, and was continually updated throughout the completion of this review.

\section{Inclusion criteria}

Studies addressing the risk of hepatitis B, hepatitis C, HIV, and prion disease transmission through the use of tonometers, were considered for inclusion in this review. Studies that included tonometer tip sterilization techniques against these identified infectious diseases were also considered for inclusion. Given the expectation that there would be limited relevant literature, restrictions were not placed on the levels of evidence required for inclusion within the review. However, it was assumed that randomized controlled trial (RCT) evidence would carry the greater interpretative weight, as this research design is considered the gold standard. Therefore, RCTs exhibit a greater intrinsic potential to address biasing effects, compared to other study design types.

\section{Study selection}

The overarching goal of the study selection was to identify and systematically review any available evidence within the eligibility boundaries previously outlined. Specific screening questions were developed for all levels of the relevance assessment, and two independent reviewers performed this screening process. Two levels of screening were completed to identify the relevant studies for this review. The first level of 


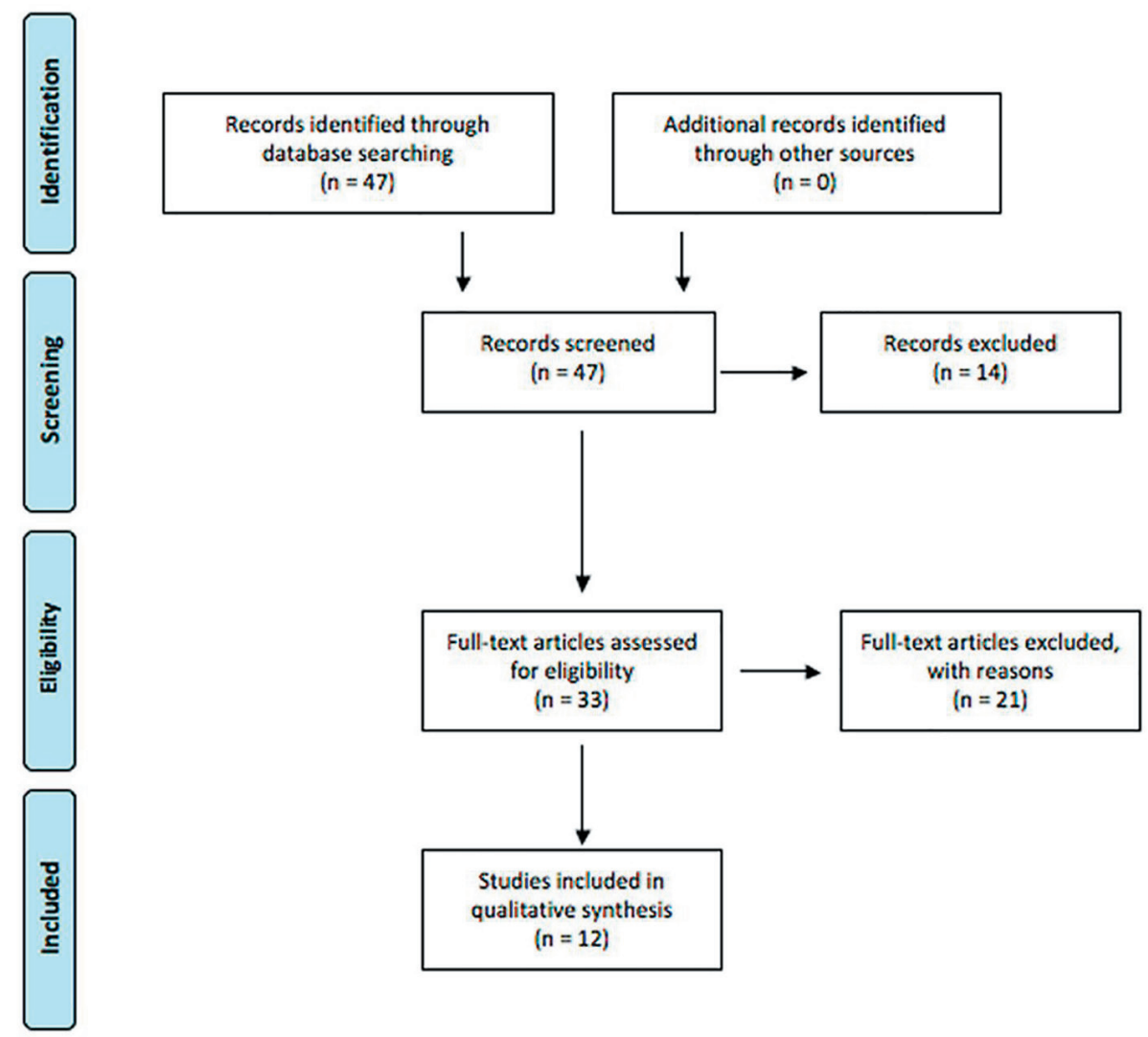

Figure 1. PRISMA diagram for article management.

screening included a title and abstract review for the articles retrieved from the electronic search, to remove any studies that did not relate to the topic of this project. The reports obtained from this screening process were uploaded to a software program (Covidence) to assist with the overall management of the articles for the review. The articles identified by either one or both reviewers as possibly relevant were retrieved for a full text review. The second level of screening involved a full text review based on the eligibility criteria outlined in the Inclusion criteria section. A full paper analysis was completed to ensure the study provided sufficient information relevant to the objective of this systematic review. Following the second level screening, the reference lists of the relevant articles were also manually searched to identify additional unique references. Disagreements arising between the two independent reviewers during the second level of screening were resolved consensually. In situations where agreement could not be attained, a third party was consulted to alleviate the impasse. Subsequent to the completion of this screening, 11 articles were identified as relevant and sufficient for this review.

\section{Study quality assessment}

A quality assessment was also performed on all of the studies included within this systematic review. The quality assessment utilized was the "Quality Checklist for Health Care In- tervention Studies", developed by Downs and Black [15]. This checklist can be utilized to assess the methodological quality of both randomized and non-randomized studies [15]. This instrument contains 27 items, and assesses the following methodological components: reporting, external validity, bias, confounding, and power [15]. However, nine items were removed from this checklist for this systematic review, as these items were irrelevant to the articles retrieved through the secondary screening process. Therefore, all articles were assigned a quality score out of a total of 18 items.

\section{Data extraction}

A data collection form was designed to extract the relevant information from the selected studies. The data collection form addressed the qualitative aspects of the relevant studies, including: author, date of publication, objective, population size, intervention, and outcome data. The outcome data extracted from the studies that passed the second level of screening, included: potential for disease transmission on tonometers (hepatitis B, hepatitis C, HIV, and prion diseases), tonometer disinfection methods, concentration of disinfection, length of application, and the reduction in viral colonies on the tonometer tips. One of the two independent reviewers abstracted the data from the selected studies, and the second reviewer independently verified the data. 


\section{Results}

The PRISMA diagram summarizing article management is shown in Figure 1. For the initial screening, 47 articles were retrieved and analyzed for relevance. During this process, 14 articles were excluded for the following reasons: not a first publication of empirical evidence, lack of focus on the transmission of infectious diseases for this systematic review, and publication of the article in a language other than English. All reports having passed this screening phase were then retrieved and subjected to a more detailed relevance assessment. A second relevance screening resulted in the exclusion of 22 reports for the following reasons: not a first publication of empirical evidence, and not related to transmission of the identified infectious diseases.

In total, 11 unique studies were deemed relevant for this systematic review. To avoid confusion within the text, tables are used to outline the results from the different studies. Of the 11 relevant studies, seven focused on the transmissibility of HIV, hepatitis B, hepatitis C, and prion disease through human tears (Table 1, [13, 16-21]). The remaining four articles compared tonometer sterilization techniques against these identified infectious diseases (Table 2, [8, 9, 22, 23]).

The articles collected for Table 1 demonstrate that tonometer tips can contribute to the transmission of prion diseases, HIV, hepatitis B, and hepatitis $\mathrm{C}$ through human tears. The research demonstrates this transmissibility through in vitro models. The data collected demonstrates the transmission of proteinacious material through the use of tonometer tips [13]. HIV also has the potential to be dispersed through tear droplets during air puff tonometry, as air puff tonometry facilitates the scatter of eye droplets in all individuals [16]. Several studies demonstrated that hepatitis B is transmissible through human tears, specifically during contact lens fitting and through the use of contact tonometry [17]. Lastly, hepatitis $\mathrm{C}$ was additionally identified as transmissible through human tears, as hepatitis C RNA was detected within the tears of chronically infected individuals [18]. Although these research studies demonstrate the transmissibility of prion disease, HIV, hepatitis B, and hepatitis $\mathrm{C}$ through in vitro models, there is a lack of evidence to identify the likelihood of transmission through in vivo models.

Table 2 summarized the available research regarding tonometry sterilization against prion diseases, HIV, hepatitis B, and hepatitis C. Several sterilization techniques were identified as effective, for each infectious disease. One of the research studies collected evaluated the adequacy of sterilization techniques against variant Creutzfeldt Jakob disease (prion disease). The sterilization technique identified as most effective against variant Creutzfeldt Jakob disease included wiping or washing the tonometer head [8]. This strategy reduced the number of Creutzfeldt Jakob cells significantly remaining on the tonometer, but neither method eliminated all of the cells [8]. The sterilization method identified as effective against HIV was the use of hydrogen peroxide or isopropyl alcohol treatments [9]. Additionally, an isopropyl alcohol soak with a cold-water wash removed the greatest amount of hepatitis $\mathrm{C}$ virus from the tonometer [22]. Lastly, a $500 \mathrm{ppm}$ chlorine soak, or a soap and water wash effectively removed all of the detectable hepatitis B DNA from a tonometer tip [23].

\section{Discussion}

Intuitively, the most effective way of sterilizing tonometers against any potential pathogen even in vitro appeals to our sense of conducting good medicine. Abutting this paradigm are clinical results, costs, and clinical efficiency. The results of the studies collected for this systematic review demonstrate that HIV, hepatitis B, hepatitis C, and prion disease are potentially transmissible through the use of tonometers, especially through in vitro models. However, these results also demonstrate variability in determining the most effective tonometer sterilization technique against these infectious diseases in vitro. Currently, there is a lack of available research regarding the transmissibility of HIV, prion disease, hepatitis B, and hepatitis $\mathrm{C}$ through in vivo models. Furthermore, it is difficult to establish the clinical rate of HIV, hepatitis B, hepatitis C, and prion disease transmission through tonometer usage as the majority of the studies included within this review analyzed in vitro growth for their outcome. Interestingly, the rates of infection from tonometer usage for all of these entities worldwide may in fact be zero despite variable sterilization techniques. Additionally, due to the variability regarding the most effective sterilization techniques, it is difficult to determine which sterilization technique is most effective or adequately effective against these infectious diseases.

Globally, millions of tonometry tests are performed daily. Consequently, it is essential for clinicians, hospital administrators, and politicians to be informed on the most effective disinfection methods against these viruses. A limitation to this systematic review is that there was limited evidence available regarding the transmission of $\mathrm{HIV}$, hepatitis $\mathrm{B}$, hepatitis $\mathrm{C}$, and prion diseases through the use of tonometers. However, the evidence did demonstrate that the use of tonometers contributes to the transmission of these infectious diseases in vitro. Therefore, one recommendation synthesized from the completion of this systematic review is increased research regarding tonometer sterilization techniques to more adequately inform infectious disease control guidelines.

The literature collected for this systematic review also received low quality scores during the study quality assessment. Consequently, subsequent high quality research should be completed. The quality of the evidence in research studies is often linked to the strength of the recommendations synthesized from the evidence. Therefore, future research studies regarding tonometer sterilization techniques should prioritize completing high quality research studies to inform clinicians, hospital administrators and politicians. In the future, high quality research on both the transmissibility of these infectious diseases and the various sterilization techniques would be beneficial to assist with informing future policies regarding infection control.

\section{Acknowledgments}

The authors would like to thank Brad Dishan, the Medical 
Table 1. Transmission of HIV, Hepatitis B, Hepatitis C, and Prion Diseases

\begin{tabular}{|c|c|c|c|c|c|}
\hline $\begin{array}{l}\text { Author } \\
\text { and year }\end{array}$ & Objective & Study design & $\begin{array}{l}\text { Popula- } \\
\text { tion size }\end{array}$ & Result & $\begin{array}{l}\text { Quality } \\
\text { score }\end{array}$ \\
\hline $\begin{array}{l}\text { Amin et al } \\
(2003)[13]\end{array}$ & $\begin{array}{l}\text { To determine the potential } \\
\text { risk of horizontal transmission } \\
\text { of proteinaceous material } \\
\text { through the use of contact } \\
\text { tonometry. How tested? }\end{array}$ & Experimental & 12 individuals & $\begin{array}{l}\text { Tonometer tips can contribute to the } \\
\text { transmission of proteinaceous material. } \\
\text { Rinsing the tonometer tips in water } \\
\text { reduced carryover of material. }\end{array}$ & $7 / 18$ \\
\hline $\begin{array}{l}\text { Darrell } \\
\text { and Jacob } \\
(1978)[17]\end{array}$ & $\begin{array}{l}\text { To determine the presence of } \\
\text { hepatitis B in human tears and } \\
\text { the risk of transferring this } \\
\text { infection through contact lens } \\
\text { fitting and contact tonometry. }\end{array}$ & Experimental & 33 individuals & $\begin{array}{l}\text { Eighteen patients were tested with } \\
\text { positive serum hepatitis B, and of } \\
\text { these } 18 \text { individuals, } 10 \text { had hepatitis } \\
\text { B in tears collected using the Schirmer } \\
\text { strip or through the contact lens } \\
\text { method. The } 15 \text { controls had no } \\
\text { hepatitis B detected in their tears. }\end{array}$ & $5 / 18$ \\
\hline $\begin{array}{l}\text { Feucht et al } \\
(1995)[18]\end{array}$ & $\begin{array}{l}\text { To determine whether the } \\
\text { tear fluid of hepatitis } \mathrm{C} \text { virus } \\
\text { carriers is infectious. }\end{array}$ & Experimental & 76 individuals & $\begin{array}{l}\text { All } 76 \text { patients chronically infected } \\
\text { with hepatitis C were positive for } \\
\text { hepatitis C RNA within tear fluid. }\end{array}$ & $6 / 18$ \\
\hline $\begin{array}{l}\text { Komatsu et al } \\
(2012)[19]\end{array}$ & $\begin{array}{l}\text { To assess the possibility of } \\
\text { transmission of hepatitis B } \\
\text { virus in tears, urine, saliva } \\
\text { and sweat. Additionally, the } \\
\text { infectivity of tears from hepatitis } \\
\text { B carriers was analyzed. }\end{array}$ & Experimental & 47 individuals & $\begin{array}{l}\text { The transmissibility of this infectious } \\
\text { disease from tears was studied in a } \\
\text { chimeric mouse model. Hepatitis B } \\
\text { tear specimens collected from a child } \\
\text { and injected intravenously into two } \\
\text { chimeric mice. One week following } \\
\text { inoculation, both mice tested positive } \\
\text { for hepatitis B DNA in their serum. }\end{array}$ & $11 / 18$ \\
\hline $\begin{array}{l}\text { Su et al } \\
(1994)[21]\end{array}$ & $\begin{array}{l}\text { To determine the transmissibility of } \\
\text { hepatitis B DNA in human tears. }\end{array}$ & Experimental & 36 individuals & $\begin{array}{l}\text { Detected that both patients with acute } \\
\text { hepatitis B (two individuals) had tear } \\
\text { specimens that were positive for HBV } \\
\text { DNA, and } 16 \text { of the } 34 \text { carriers of } \\
\text { chronic HBV had tear specimens that } \\
\text { tested positive repeatedly for HBV } \\
\text { DNA. The tear specimens of } 10 \text { of the } 34 \\
\text { individuals with chronic HBV repeatedly } \\
\text { tested negative, and the remaining } \\
\text { eight tear specimens were equivocal. }\end{array}$ & $8 / 18$ \\
\hline
\end{tabular}

The table demonstrates the results regarding the transmissibility of HIV, hepatitis $\mathrm{B}$, hepatitis $\mathrm{C}$, and prion diseases through human tears.

Librarian at St. Joseph's Hospital in London, Ontario, for his assistance with the electronic literature search. The authors would also like to thank Meryl Brown for her assistance with the revision process for this review. 
Table 2. Tonometer Sterilization Techniques

\begin{tabular}{|c|c|c|c|c|c|c|}
\hline $\begin{array}{l}\text { Author } \\
\text { and year }\end{array}$ & Objective & Study design & $\begin{array}{l}\text { Population } \\
\text { size }\end{array}$ & $\begin{array}{l}\text { Sterilization tech- } \\
\text { niques mentioned }\end{array}$ & Result & $\begin{array}{l}\text { Quality } \\
\text { score }\end{array}$ \\
\hline $\begin{array}{l}\text { Segal et al } \\
(2001)[22]\end{array}$ & $\begin{array}{l}\text { To compare } \\
\text { decontamination } \\
\text { methods for } \\
\text { Goldmann } \\
\text { tonometers } \\
\text { containing } \\
\text { hepatitis C virus. }\end{array}$ & Experimental & one individual & $\begin{array}{l}\text { The sterilization techniques } \\
\text { for the tonometer } \\
\text { compared included: a } 5 \\
\text { min soak in } 3 \% \text { hydrogen } \\
\text { peroxide or } 70 \% \text { isopropyl } \\
\text { alcohol (wipes or soak), } \\
\text { dry gauze wipes, and a } \\
\text { wash in cold water. }\end{array}$ & $\begin{array}{l}\text { The isopropyl alcohol soak and } \\
\text { cold water washed removed } \\
\text { the greatest percentage of } \\
\text { hepatitis C virus from the } \\
\text { tonometer. A } 5 \text { min soak in } \\
\text { either solution followed by } \\
\text { washing in cold water is most } \\
\text { effective at reducing the risk of } \\
\text { hepatitis C virus transmission. }\end{array}$ & $7 / 18$ \\
\hline $\begin{array}{l}\text { Pepose et } \\
\text { al (1989) } \\
{[9]}\end{array}$ & $\begin{array}{l}\text { To test several } \\
\text { protocols for the } \\
\text { disinfection of } \\
\text { Goldmann tonometer } \\
\text { tips against HIV- } \\
1 \text {, herpes simplex } \\
\text { virus type } 1 \text {, and } \\
\text { HSV type } 2 \text {. }\end{array}$ & Experimental & one individual & $\begin{array}{l}\text { The sterilization techniques } \\
\text { for the tonometer compared } \\
\text { included: hydrogen } \\
\text { peroxide, isopropyl } \\
\text { alcohol treatments, sterile } \\
\text { gauze and sterile tissue. }\end{array}$ & $\begin{array}{l}\text { The hydrogen peroxide and } \\
\text { isopropyl alcohol treatments } \\
\text { were both effective for } \\
\text { disinfection of the tonometer } \\
\text { tip against HIV. Wiping the } \\
\text { tip with a sterile gauze or } \\
\text { tissue was not effective. }\end{array}$ & $6 / 18$ \\
\hline $\begin{array}{l}\text { Lim et al } \\
(2003)[8]\end{array}$ & $\begin{array}{l}\text { To evaluate the } \\
\text { adequacy of current } \\
\text { decontamination } \\
\text { techniques for the } \\
\text { Goldmann tonometer } \\
\text { against variant } \\
\text { Creutzfeldt Jakob } \\
\text { disease (vCJD). }\end{array}$ & Experimental & 69 individuals & $\begin{array}{l}\text { The sterilization technique } \\
\text { mentioned involved: } \\
\text { wiping the tonometer } \\
\text { head with tissue, wiping } \\
\text { with tissue + sodium } \\
\text { hypochlorite solution } \\
\text { for } 10 \text { min, under } \\
\text { water with tissue, and } \\
\text { then placing in sodium } \\
\text { hypochlorite for } 10 \mathrm{~min} .\end{array}$ & $\begin{array}{l}\text { Patients using eye drops } \\
\text { desquamated an increased } \\
\text { amount of corneal epithelial } \\
\text { cells using Goldmann } \\
\text { tonometry compared to } \\
\text { patients who did not. Wiping } \\
\text { or washing the tonometer } \\
\text { head reduced but did not } \\
\text { eliminate the number of } \\
\text { cells significantly. }\end{array}$ & $11 / 18$ \\
\hline $\begin{array}{l}\text { Su et al } \\
(1994)[23]\end{array}$ & $\begin{array}{l}\text { To determine } \\
\text { which tonometer } \\
\text { disinfection methods } \\
\text { are most effective } \\
\text { against hepatitis B. }\end{array}$ & Experimental & - & $\begin{array}{l}\text { The disinfection procedures } \\
\text { outlined in this study } \\
\text { included: soap and water } \\
\text { wash, a } 70 \% \text { isopropanol } \\
\text { wipe, a } 70 \% \text { ethanol } \\
\text { wipe, a wipe with distilled } \\
\text { water, a } 500 \text { ppm chlorine } \\
\text { soak ( } 10 \text { min), a } 11 \% \\
\text { glutareldehyde soak ( } 10 \\
\text { min), and a tap water rinse. }\end{array}$ & $\begin{array}{l}\text { A soap and water wash } \\
\text { removed all of the detectable } \\
\text { hepatitis B DNA. A } 500 \mathrm{ppm} \\
\text { chlorine soak removed the } \\
\text { detectable HBV DNA in } \\
\text { some of the trials. The other } \\
\text { methods resulted in residual } \\
\text { HBV DNA remaining. }\end{array}$ & $4 / 18$ \\
\hline
\end{tabular}

The following table demonstrates the results regarding tonometer sterilization techniques against HIV, hepatitis B, hepatitis C, and prion disease.

\section{Financial Support}

None.

\section{Conflict of Interest}

None.

\section{References}

1. Quigley HA, Broman AT. The number of people with glaucoma worldwide in 2010 and 2020. Br J Ophthalmol.
2006;90(3):262-267.

2. Einarson TR, Vicente C, Machado M, Covert D, Trope GE, Iskedjian M. Screening for glaucoma in Canada: a systematic review of the literature. Can J Ophthalmol. 2006;41(6):709-721.

3. Briesen S, Schulze Schwering M, Roberts H, Kollmann M, Stachs O, Behrend D, Schafer S, et al. Minimal crossinfection risk through Icare rebound tonometer probes: a useful tool for IOP-screenings in developing countries. Eye (Lond). 2010;24(7):1279-1283.

4. Heijl A. Perimetry, tonometry and epidemiology: the fate of glaucoma management. Acta Ophthalmol. 2011;89(4):309-315.

5. Cook JA, Botello AP, Elders A, Fathi Ali A, Azuara-Blanco A, Fraser C, McCormack K, et al. Systematic review 
of the agreement of tonometers with Goldmann applanation tonometry. Ophthalmology. 2012;119(8):1552-1557.

6. Farrell SM, Dooley I, O'Connell E, Bashir S, Foley-Nolan A, Kearns F, Logan P, et al. Comparing the Tonojet disposable tonometer with the traditional Goldmann tonometer in glaucomatous and non-glaucomatous eyes. Int Ophthalmol. 2013;33(4):367-374.

7. Desai SP, Sivakumar S, Fryers PT. Evaluation of a disposable prism for applanation tonometry. Eye (Lond). 2002;16(5):675.

8. Lim R, Dhillon B, Kurian KM, Aspinall PA, Fernie K, Ironside JW. Retention of corneal epithelial cells following Goldmann tonometry: implications for CJD risk. Br J Ophthalmol. 2003;87(5):583-586.

9. Pepose JS, Linette G, Lee SF, MacRae S. Disinfection of Goldmann tonometers against human immunodeficiency virus type 1. Arch Ophthalmol. 1989;107(7):983-985.

10. Cillino S, Casuccio A, Giammanco GM, Mammina C, Morreale D, Di Pace F, Lodato G. Tonometers and infectious risk: myth or reality? Efficacy of different disinfection regimens on tonometer tips. Eye (Lond). 2007;21(4):541-546.

11. Arora S, Roelofs K, Damji KF. Tonometer tip disinfection: principles, evidence, and importance of end-user engagement in policy formulation. Can J Ophthalmol. 2013;48(3):136-137.

12. Omar Akhtar A, Singh H, Si F, Hodge WG. A systematic review and cost-effectiveness analysis of tonometer disinfection methods. Can J Ophthalmol. 2014;49(4):345350 .

13. Amin SZ, Smith L, Luthert PJ, Cheetham ME, Buckley RJ. Minimising the risk of prion transmission by contact tonometry. Br J Ophthalmol. 2003;87(11):1360-1362.

14. Chandra A, Barsam A, Hammond CJ. Tonometer prism sterilisation: a local and UK national survey. Cont Lens Anterior Eye. 2008;31(1):13-16.

15. Downs SH, Black N. The feasibility of creating a checklist for the assessment of the methodological quality both of randomised and non-randomised studies of health care interventions. J Epidemiol Community Health. 1998;52(6):377-384.

16. Britt JM, Clifton BC, Barnebey HS, Mills RP. Microaerosol formation in noncontact 'air-puff' tonometry. Arch Ophthalmol. 1991;109(2):225-228.

17. Darrell RW, Jacob GB. Hepatitis B surface antigen in human tears. Arch Ophthalmol. 1978;96(4):674-676.

18. Feucht HH, Zollner B, Schroter M, Altrogge H, Laufs R. Tear fluid of hepatitis $\mathrm{C}$ virus carriers could be infectious. J Clin Microbiol. 1995;33(8):2202-2203.

19. Komatsu H, Inui A, Sogo T, Tateno A, Shimokawa R, Fujisawa T. Tears from children with chronic hepatitis $B$ virus (HBV) infection are infectious vehicles of HBV transmission: experimental transmission of $\mathrm{HBV}$ by tears, using mice with chimeric human livers. J Infect Dis. 2012;206(4):478-485.

20. Moniz E, Feldman F, Newkirk M, Feinman SV, Berris B. Removal of hepatitis B surface antigen from a contaminated applanation tonometer. Am J Ophthalmol. 1981;91(4):522-525.

21. Su CS, Bowden S, Fong LP, Taylor HR. Detection of hepatitis B virus DNA in tears by polymerase chain reaction. Arch Ophthalmol. 1994;112(5):621-625.

22. Segal WA, Pirnazar JR, Arens M, Pepose JS. Disinfection of Goldmann tonometers after contamination with hepatitis C virus. Am J Ophthalmol. 2001;131(2):184-187.

23. Su CS, Bowden S, Fong LP, Taylor HR. Current tonometer disinfection may be inadequate for hepatitis B virus. Arch Ophthalmol. 1994;112(11):1406-1407. 